\title{
Omeprazole and misoprostol for preventing gastric mucosa effects caused by indomethacin and celecoxib in rats ${ }^{1}$
}

\author{
Omeprazol e misoprostol na prevenção de lesões de mucosa gástrica causadas por \\ indometacina e celecoxib em ratos
}

\author{
Míriam Elias Cavallini², Nelson Adami Andreollo ${ }^{3}$,Konradin Metze ${ }^{4}$, Marina Raquel Araújo $^{5}$ \\ 1. Research developed in Post-graduation Program performed in the Enzimology and Experimental Carcinogenesis Laboratory, Surgery \\ Department, Faculty of Medical Sciences of State University of Campinas (UNICAMP-FCM), São Paulo. Brazil. \\ 2. Assistant Professor of Methodist University Piracicaba, São Paulo. Brazil. \\ 3. Associate Professor, Surgery Department, UNICAMP, São Paulo. Brazil. \\ 4. Associate Professor, Pathology Department, UNICAMP, São Paulo. Brazil. \\ 5. Biologist, Enzimology and Experimental Carcinogenesis Laboratory, UNICAMP, São Paulo. Brazil.
}

\begin{abstract}
Purpose: To evaluate and to compare macro and microscopically the intense injuries of the gastric mucosa of rats which were caused by NSAIDS celecoxib and indomethacin and the gastric cytoprotection with omeprazole and misoprostol. Methods: The sample is formed by one hundred and fifty Wistar rats with average weight $200 \mathrm{~g}$, distributed in four groups, such as: Group A, subdivided in groups A1 and A2 - pre-treatment with omeprazole ( $20 \mathrm{mg} / \mathrm{rat})$ during seven days and on the $8^{\text {th }}$ day - use of NSAIDS, concerning A1 (20 rats) were given celecoxib (1mg/rat) and A2 (20 rats) were given indomethacin. The Group B, subdivided in group B1 and B2 - pre-treatment with misoprostol (20mg/rat) during seven days and on the $8^{\text {th }}$ day use of NSAIDS, concerning B1 (20 rats) were given celecoxib (1 mg/rat) and B2 (20 rats) were given indomethacin (12.5 mg/rat). The Group C: were not given cytoprotection during seven days, from the $7^{\text {th }}$ to the $8^{\text {th }}$ day - fast of food and water ad libitum, on the $8^{\text {th }}$ day of NSAIDS use, concerning C1 (20 rats) were given celecoxib, C2 (20 rats) were given indomethacin (12.5 mg/rat), C3 (20 rats) were given celecoxib (200mg/rato), and Group D - control group, concerning 10 rats were observed during seven days ingesting food and water ad libitum. On the $9^{\text {th }}$ day, the stomachs were taken out and were macro and microscopically evaluated for the identification of the gastric injuries. Results: On the macroscopic studies, the groups A2, B2 and C2 presented a remarkable high number of injuries for $\mathrm{cm}^{2} /$ animal, respectively 18.55 injuries for $\mathrm{cm}^{2}$ /animal, 16.25 injuries for $\mathrm{cm}^{2}$ /animal and 13.55 injuries for $\mathrm{cm}^{2} /$ animal. On the microscopic studies, the percentage of the injured mucosa, presented expressive difference among the groups A1, B1, C1 when compared to the groups A2, B2, C2 ( $<<0.0001)$. The average of the length/injury and the average of the depth of the injuries did not present expressive statistics differences among the groups A2, B2 and C2. The average of the edema presented expressive statistics difference among the groups A2 and D; B2 and C2 and between C2 and D $(\mathrm{p}<0.05)$. Conclusions: The indomethacin on the applied concentration causes a great number of macroscopic and microscopic injuries to gastric mucosa of rats when compared to celecoxib which does not cause lesions. Omeprazole and misoprostol on the applied concentrations do not present macroscopic and microscopic effectiveness on the gastric cytoprotection when applying indomethacin. Considering the microscopic analysis of the average of the edema, the group of animals, which was given misoprostol as cytoprotection, presented a lower average compared to the group which was given omeprazole.
\end{abstract}

Key words: Anti-Inflammatory Agents, Non-Steroidal. Gastric Mucosa. Stomach. Pharmacology.

\section{RESUMO}

Objetivo: Avaliar e comparar macro e microscopicamente as lesões agudas da mucosa gástrica de ratos provocadas pelos AINEs celecoxib e indometacina e a citoproteção gástrica com omeprazol e misoprostol. Métodos: A amostragem consistiu 150 ratos machos da raça Wistar, com peso médio de 200g, divididos em quatro grupos, a saber: grupo A, subdividido em grupos A1 e A2 - pré-tratamento com omeprazol ( $20 \mathrm{mg} / \mathrm{rato})$ durante sete dias, e no oitavo dia receberam o AINEs, sendo A1 (20 ratos) receberam celecoxib ( $1 \mathrm{mg} /$ rato) e A2 (20 ratos) receberam indometacina (12,5mg/rato). O grupo B, subdividido em grupo B1 e B2 - pré-tratamento com misoprostol (20ìg/rato) durante sete dias e no oitavo dia receberam AINEs, sendo B1 (20 ratos) receberam celecoxib (1mg/rato) e B2 (20 ratos) receberam indometacina (12,5mg/rato). O grupo C não recebeu citoproteção durante sete dias e no oitavo dia recebeu AINEs, sendo C1 (20 ratos) receberam celecoxib (1mg/rato) , C2 (20ratos) receberam indometacina (12,5mg/rato), C3 (20 ratos) receberam celecoxib e grupo D - grupo controle, no qual dez ratos foram observados recebendo ração e água ad libitum. A seguir, no $9^{\circ}$ dia (de todos os grupos), os estômagos eram removidos e avaliados macro e microscopicamente para a identificação das lesões gástricas. Resultados: Na análise macroscópica, os grupos A2, B2 e C2 apresentaram número de lesões por $\mathrm{cm}^{2} /$ animal significativamente elevados, sendo respectivamente 18,55 lesões por $\mathrm{cm}^{2} /$ animal, 16,25 lesões por $\mathrm{cm}^{2} /$ animal e 13,55 lesões por $\mathrm{cm}^{2} /$ animal. Na análise 
microscópica, a porcentagem da mucosa com lesão mostrou diferença significativa entre os grupos A1, B1, C1 quando comparados com os grupos A2, B2 e C2 (p<0,0001). Os resultados da média da extensão/lesão e da média da profundidade das lesões não mostraram diferenças estatísticas significativas entre os grupos A2, B2 e C2. A média do edema mostrou diferença estatística significativa entre os grupos A2 e D; B2 e C2 e entre C2 e D $(p<0,05)$. Conclusões: A indometacina na concentração empregada provoca número significativo de lesões macro e microscópicas na mucosa gástrica de ratos quando comparadas ao celecoxib, que não provocou lesões. O omeprazol e o misoprostol nas concentrações empregadas não mostraram efetividade macro e microscópica na citoproteção gástrica à administração da indometacina. Considerandose a análise microscópica da média do edema, o grupo de animais que recebeu misoprostol como citoprotetor apresentou menor média em comparação ao grupo que recebeu o omeprazol.

Descritores: Antiinflamatórios não Esteróides. Mucosa Gástrica. Estômago. Farmacologia.

\section{Introduction}

The specialized literature points out that 300 million of people all over the world use non steroidal antiinflammatories drugs (NSAIDs) and $1.2 \%$ of the population in the USA take these agents everyday. Also, 100 million of NSAIDs prescriptions yearly, are considered ${ }^{1,2}$. Actually, $8 \%$ of the old population has, at least, one chronic disease and most of them have two, and an important information is that there will be approximately 750 million of people aged more than 65 years old in the world until 2050. The use of medicaments increases according to the age, mainly due to the amount of diseases which are higher ${ }^{3}$.

The use of several medicaments causes many symptoms and gastrointestinal diseases, and it is important to stress that the digestive diseases are significant causes of old people's morbidity and mortality ${ }^{3}$. The long period of NSAIDs use causes erosions in the gastroduodenal mucosa to approximately $35 \%$ - $60 \%$ of the patients, peptic or duodenal ulcers to $10 \%-25 \%$ and serious complications, such as hemorrhage or gastrointestinal perforation ${ }^{4}$.

Considering only the patients who have rheumatoidal arthritis, 20.000 hospitalizations and 2,600 deaths a year are registred, due to the toxicity related to NSAIDs. Exceeding these data, considering all the population who uses NSAIDs in the United States, more than 100,000 hospitalizations and 10,000 to 20,000 deaths a year are due to the gastrointestinal complications related to NSAIDs, having a cost exceeding 4 billion a year ${ }^{5,6}$. Not only patients aged more than 65 years old but also young people can have gastric injuries caused by NSAIDs ${ }^{7,8}$. These studies show the importance of the upper digestive endoscopy, which detect even asymptomatical injuries ${ }^{9}$.

The upper digestive endoscopy studies on rheumatic patients who had a long periods of treatments with NSAIDs, confirmed a high incidence of gastric and duodenal lesions. The ocurrence for peptic ulcers was $17 \%$ and erosions $40 \%$; for duodenal ulcers $4 \%$ and erosion $13 \%{ }^{10}$. Otherwise, the physiopathology of the peptic diseases can be considered as an unstability among the injurious factors (acid, pepsin, infection by Helicobacter pylori) and the protective factors (bicarbonate secretion, mucous and prostaglandins). The current treatments are directed to the reduction of the injurious factors and to strength the mucosa protections of the stomach and duodenum through the cytoprotector agents ${ }^{9}$.
The antacids were the unique neutralizers of the gastric acid used to relieve the symptoms of the ulcers during several years. Although the gastric acidity had been responsible as the main etiologic factor of the peptic ulcer, the researches pointed toward the ways where the gastric mucous usually protect itself from injurious agents suggesting additional terapeutic focus. The new drugs which reduce the acid gastric secretion $\left(\mathrm{H}_{2}\right.$ blockers and the inhibitors of the bomb proton) promote the ulcer cicatrization and they are the most used ones. The cytoprotector agents (sucralfate, colloidal bismuth and the misoprostol) and the antacids also have confirmed efficiency in the literature ${ }^{11}$.

The main therapeutical effects of NSAIDs are its ability of inhibits the prostaglandin synthesis, whose generalization is performed in a progressive way throughout a abnormal complex of enzymes. The first enzyme which takes part of this procedure is the synthesis of the prostaglandin endoperoxide, also known as ciclooxygenase. There are two isoforms of this enzyme, ciclooxygenases 1 and 2 (denominated COX-1, COX-2). The first one is a determinative isoform, found in the blood vessels, stomach and livers, which acts as gastric cytoprotector while COX2 is induced in the inflammatory context by the citokines and intermediaries of the inflammation ${ }^{12}$.

The NSAIDs, besides having several therapeutical activities in common, however present many side effects, such as: ulceration and gastrointestinal intolerance; changes in the platelet aggregation (inhibition of the tromboxano synthesis); decreasing of the uterine motility (extension of the pregnancy; decreasing of the renal functions interfered by the prostaglandins and hypersensitivity reactions ${ }^{13}$.

Considering all the side effects mentioned above, the most common one, regarding the facts, is the tendency to produce gastric or intestinal ulceration which, in some cases associated with a secondary bleeding and anaemia . Other authors show that patients who take NSAIDs for long periods of time, have three times more chance to develop collateral gastrointestinal complications, compared to the patients who do not take these drugs ${ }^{14}$.

Recently a new NSAIDs named “coxibs”.arise, having complications rate lower than the traditional drug, The “coxibs" represent an important pharmacological advance in the anti-inflammatory treatment, reducing the 
gastrointestinal injuries, once they are specific inhibitor of the COX-2 ${ }^{15}$. Regarding the gastric cytoprotector, there are several therapeutic strategies, according to the following distribution: antacid agents, cytoprotector agents, antagonists of $\mathrm{H}_{2}$ receptor, muscarínic antagonist, agonists of prostaglandin and inhibitors of $\mathrm{H}^{+}, \mathrm{K}^{+}$- ATPase ${ }^{11}$. The statistics of serious injuries caused to people who use NSAIDs all over the world and the importance of the gastric cytoprotection, besides the recent advances with the introduction of drugs with seletive inhibitor of the COX-2, therapeutical advancements were afforded, once this enzyme probably is involved in the production of prostaglandins ${ }^{10,14}$. The objective of this research is to study the injuries caused by indomethacin and celecoxib and compares the cytoprotector action of the omeprazole and misoprostol.

\section{Methods}

The research had previous approval by The Ethic Committee on the Animal Trial in the Biology Institute. One hundred and fifty male Wistar rats, three months old and $200 \mathrm{~g}$ average weight, being considered healthy and free from specific diseases (SPF - Specific Pathogen Free), were employed. The animals were arranged in groups of 10 , they had been kept in environmental temperature, with daylight cycles, under a continuous air flow; they were given food and water ad libitum, always remaining in the same cage until the end of the study. The cages were always handled by the same laboratory expert, who was especially trainned for this position. He wore suitable footwears, aprons and gloves and cleaned the cages three times a week.

\section{Drugs and dilution}

All the drugs were administrated intragastrically:

- Indometacin : $12,5 \mathrm{mg} /$ rat, dilluted in fltrate water (01 cachet - 25mg in 2ml) - (groups A2; B2 and C2) (Indocid $^{\circledR}$ - Prodome Laboratory)

- $\quad$ Celecoxib ${ }^{\circledR}$ : one $200 \mathrm{mg}$ tablet, dilluted in $200 \mathrm{ml}$ of water (1mg/ rat) - (Groups A1 and C1); one 200mg tablet dilluted in water $(200 \mathrm{mg} / \mathrm{rat})-\left(\right.$ Group C3) $-\left(\right.$ Celebra ${ }^{\circledR}$ - Pharmacia Laboratory-Brasil Ltda).

- $\quad$ Omeprazole :20mg/ rat - 1 tablet (20mg) diluted in $1 \mathrm{ml}$ of water - (Group A1) - Losec ${ }^{\circledR}$ - Astrozenica Laboratory)

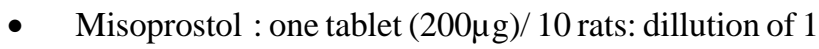
tablet in $20 \mathrm{ml}(2 \mu /$ rat $)$ - (Group B1) - (Cytotec $^{\circledR}$ Pharmacia Laboratory - Brasil Ltda)

\section{Animal groups and experimental design}

The animals were put in cages, there were five rats in each one, which were distributed in groups of 20 ones.

Group A: Pre-treatment with omeprozole Group A1: celecoxib - 20 rats Group A2: indomethacin - 20 rats
Forty rats were pre treated daily (during 7 days) with omeprazole. From the $7^{\text {th }}$ to the $8^{\text {th }}$ day, they fasted for 24 hours, 20 of them were given celecoxib and 20 were given indomethacin. After taking NSAIDs, they fasted for 6 hours. So, the animals were sacrificed on the $9^{\text {th }}$ day, due to anaesthetic overload of sodic tiopental and the stomach were removed for examination of the gastric injuries.

$$
\begin{aligned}
& \text { Group B: Pre-treatment with misoprostol } \\
& \text { Group B1: celecoxib - } 20 \text { rats } \\
& \text { Group B2: indomethacin - } 20 \text { rats }
\end{aligned}
$$

Forty rats were pre-treated daily (during 7 days) with misoprostol. From the $7^{\text {th }}$ to the $8^{\text {th }}$ day, they fasted for 24 hours, 20 of them were given celecoxib and 20 were given indomethacin. After taking NSAIDs, they fasted for 6 hours. Again, the animals were sacrificed on the $9^{\text {th }}$ day due to anaesthetic overload of sodic tiopental and the stomach were removed for examination of the gastric injuries.

$$
\begin{aligned}
& \text { Group C: no cytoprotection } \\
& \text { Group C1: celecoxib (1mg/ rat) - } 20 \text { rats } \\
& \text { Group C2: indomethacin - 20 rats } \\
& \text { Group C3: celecoxib (200mg/ rat) - } 20 \text { rats }
\end{aligned}
$$

Sixty rats were not protected with cytoprotector drug, they fasted during 24 hours before taking NSAIDs, 40 of them were given celecoxib and 20 were given indomethacin, fasting for more six hours after taking NSAIDs and were sacrificed on the following day.

\section{Group D: Control}

Ten animals were kept and observed in the Laboratory during 9 days and just fed with usual food and water ad libitum. Between the $8^{\text {th }}$ and the $9^{\text {th }}$ days, the animals fasted for 24 hours. After this period, they were sacrificed and had their stomachs removed, according to the technique described previously. The animals were observed daily in order to verify the possible behavior and/or physiological changes. All the animals were given rodent common food, ad libitum, and it was changed once a week.

\section{Euthanasia of the animals}

The stomach of the animals were removed through a laparotomy, exposition of the abdominal cavity after they had been anaesthetized with sodic tiopental. The internal part of the removed stomachs were given $2 \mathrm{ml}$ of bungged formalin $7,2 \%$ and 5 minutes afterward, they were opened through the greater curvature, from the pylorus to the cardia. After the surgical parts were removed, the animals were submitted to euthanasia through overload of sodic tiopental.

\section{Macroscopic analysis}

The stomach, when opened, was put on a flat glass plate in order the injuries could be counted, according to Takagi et al. ${ }^{16}$ standardization. In order to count the injuries, a $10 \times 10 \mathrm{~cm}$ squared glass plate was made, according to the following Figure 1. 


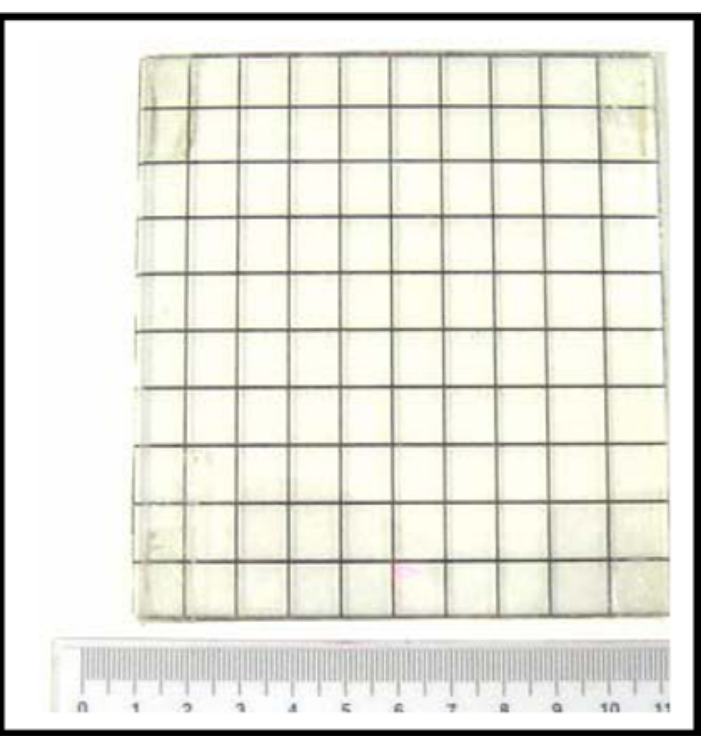

FIGURE 1 - 10x10cm flat glass plate, squared $(1 \mathrm{cmx} 1 \mathrm{~cm})$

Afterwards, the injuries were counted, putting the squared glass plate on the flat glass plate, according to the following Figure 2. The fragments were divided longitudinally, and at least, less than half of the stomach of each animal was included at random on the histopathologic screens for arrangement. Then, the screens, containing the fragments, were first plunged into $7,2 \%$ formaldehyde during 24 hours and then into alcohol $70 \%$ for 72 hours. Afterwards, the histological cuts were carried through.

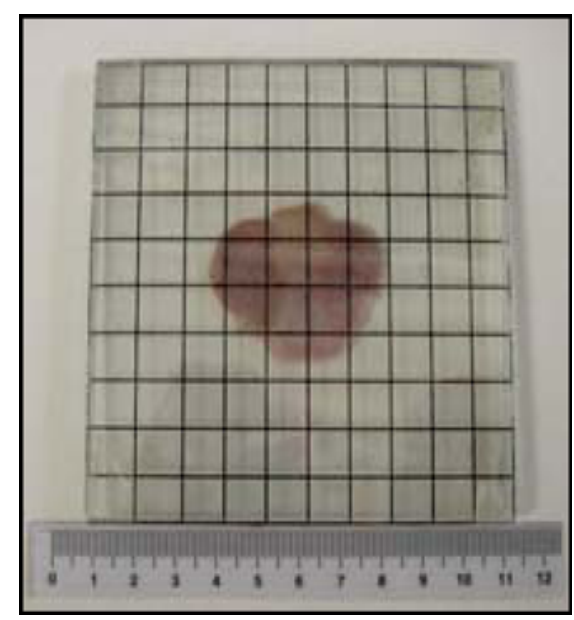

FIGURE 2 - Opened stomach, overlaid squared flat glass plate, exposing the mucous, showing the counting methodology of the injuries per $\mathrm{cm}^{2}$

\section{Microscopic analysis}

The pieces were cut using razor of Leika 858 section and arranged in histologic screens, performing longitudinal cuts. The fragments were dehydrated by crescent alcohol, made diaphanous with xylol, included into paraffin and undergone microthome adjusted to $5 \mu \mathrm{m}$ thickness and coloured by Hematoxylin and Eosin (HE) technique. At the end, the histologic investigations was carried out through a light microscope with objectives and binocular viewer which generated a final magnification 200 and 400 times. In the microscopic analysis the following were evaluated:

a) Percentage of the mucosa of each animal which had injury, was computed according to the formula below and the results were shown as percentage of the injured mucosa ${ }^{16}$.

Percentage of the injured mucosa $=\Sigma$

$\Sigma=$ horizontal extension of the injuries

$\Sigma$ total extension of the fragments

b) The extension, the depth and the edema of each injury ${ }^{16}$, considering:

b.1) Horizontal extension in mm of each injury and the results shown as extension/injury average;

b.2) Depth of the injuries, for each one, the comparative depth of each injury was computed, according to the following formula.

comparative depth $=\frac{\text { Depth of the erosive or ulcerative injury }}{\text { Depth of the mucosa }}$

The results are shown as average of the injury depth, in percentage

b.3) Edema of the injuries; for each injury the edema index was computed according to the following formula :

oedema index $=\quad$ submucosa thickness thickness of the muscular layer

The results are shown as quotient of the edema average.

\section{Results}

\section{Macroscopic analysis}

The averages of the injuries per $\mathrm{cm}^{2} /$ animal are shown in the Figure 3, as the following groups of animals:

Group A: Group of animal which were given as pre-treatment (cytoprotection): omeprazole and afterwards they were given NSAIDs celecoxib or indomethacin (Figure 3).

Group A1: Group of animals which were given celecoxib, after a pre-treatment with omeprozole. 4 injuries per $\mathrm{cm}^{2}$ were found, therefore an average of 0,2 injuries per $\mathrm{cm}^{2} /$ animal.

Group A2: Group of animals which were given indomethacin, after a pre-treatment with omeprozole. 371 injuries per $\mathrm{cm}^{2}$ were found relating to an average of 18,55 injuries per $\mathrm{cm}^{2}$ /animal . So the amount of 
injuries per $\mathrm{cm}^{2} /$ animal in the group A2 was significantly higher than the group A1.

Group B: Group of animal which were given as pre-treatment (cytoprotection): misoprostol and afterwards they were given the NSAIDs celecoxib or indomethacin (Figure 3).

Group B1: Group of animals which were given celecoxib after a pre-treatment with misoprostol, 9 injuries per $\mathrm{cm}^{2}$ were found, totalizing, therefore, the average of 0,45 injuries per $\mathrm{cm}^{2} /$ animal.

Group B2: Group of animals which were given indomethacin after a pre-treatment with misoprostol. 325 injuries/ $\mathrm{cm}^{2}$ were found, therefore the average of 16,25 injuries per $\mathrm{cm}^{2}$ /animal. This way, the amount of injuries per $\mathrm{cm}^{2}$ /animal in the group B2 was significantly higher than the group B1. Figure 4 shows these results.

Group C: No cytoprotection (Figure 3).

Group C1: Group of animals which were given celecoxib (1mg/rat). Macroscopic injuries were not found in the animals' mucosa.

Group C2: Group of animals which were given indomethacin. 271 injuries per $\mathrm{cm}^{2}$ were found, which corresponds to the average of 13,55 injuries per $\mathrm{cm}^{2} /$ animal. The data above show that the amount of injuries per $\mathrm{cm}^{2}$ /animal in the group C2 was significantly higher than the group $\mathrm{C} 1$.

Group C3: Group of animals which were given celecoxib (200mg/rat). Macroscopic injuries were not found in the animal's mucosa.

Group D: Control. Animals which were given just water and usual food during the trial and none injuries were found.

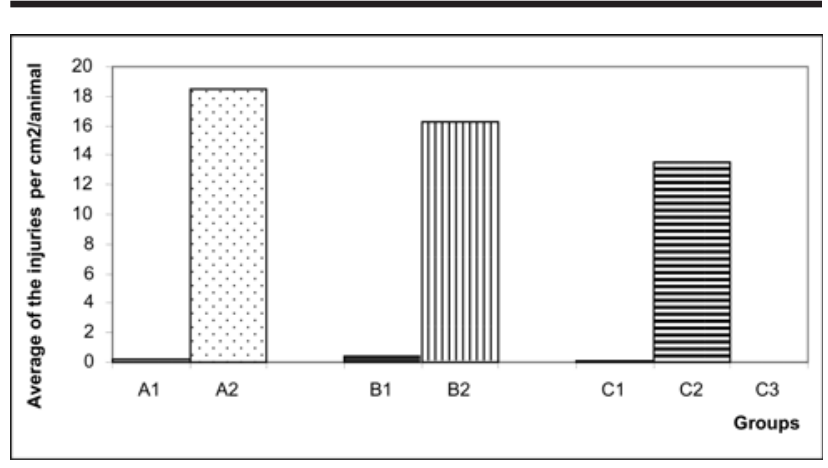

FIGURE 3 - Average of the injuries per $\mathrm{cm} 2$ /animal in the group of animals which were given celecoxib (A1) and indomethacin (A2) respectively, after a pretreatment with omeprazole

\section{Microscopic analysis}

a) Percentage of the injured mucosa showed in the Figure 4 .

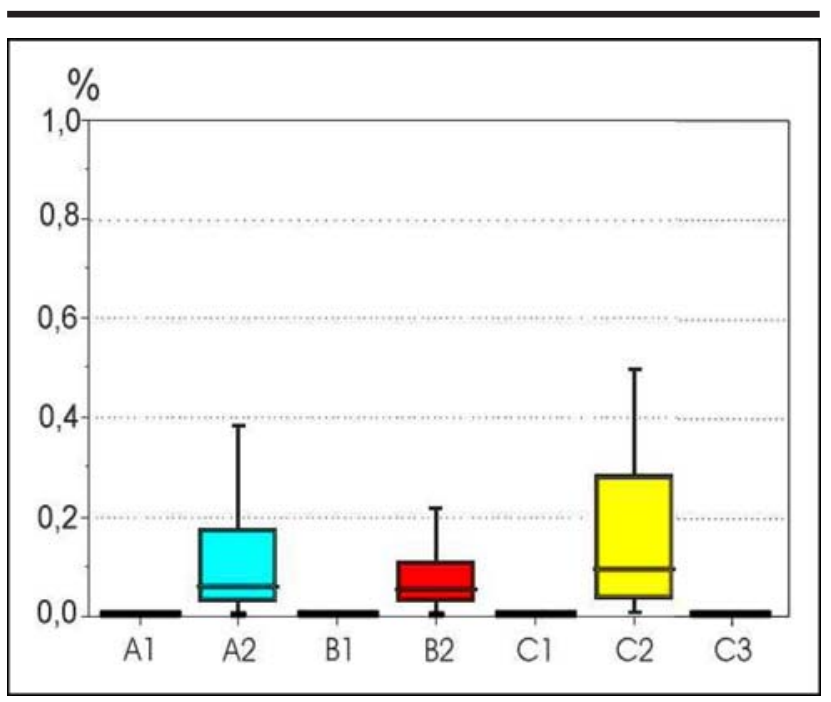

FIGURE 4 - Diagram “Box and Whiskers” of the microscopy study of the injured mucosa percentage, showing the percents 5, 25, 50, 75 and 95 of each studied group. The statistic analysis through Kruskall Wallis trial showed expressive difference among the groups A1, B1, C1 and A2, B2, C2 ( $<0.0001)$

b) Extension, depth and edema of each injury.

b.1) Average of the extension/injury showed in the Figure 5

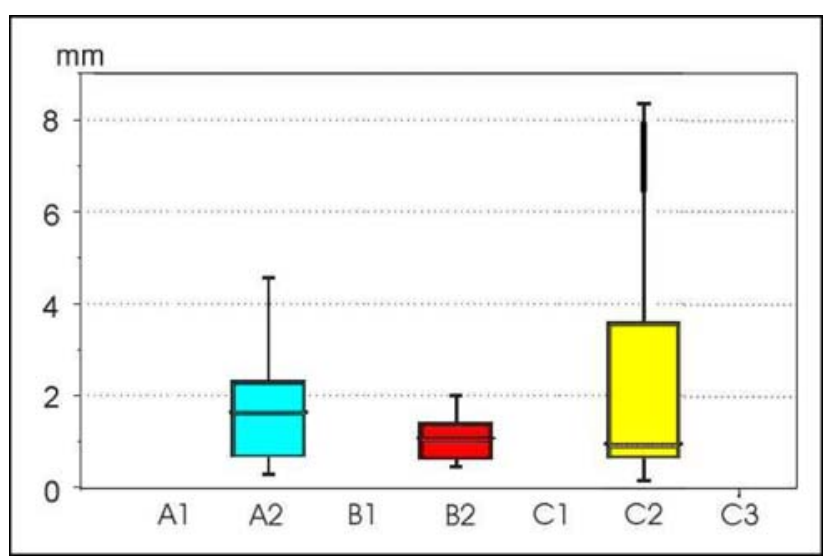

FIGURE 5 - Diagram “Box and whiskers” of the microscopic study of the extension average/injury in mm, showing the percentis 5, 25, 50, 75 and 95 of each studied group. The statistic analysis through Kruskall Wallis trial did not show difference among the groups A2, B2 and C2 ( $\mathrm{p}=0.62)$

b.2) Average of the injury depth showed in the Figure 6 .

b.3) Edema average showed in the Figure 7. 


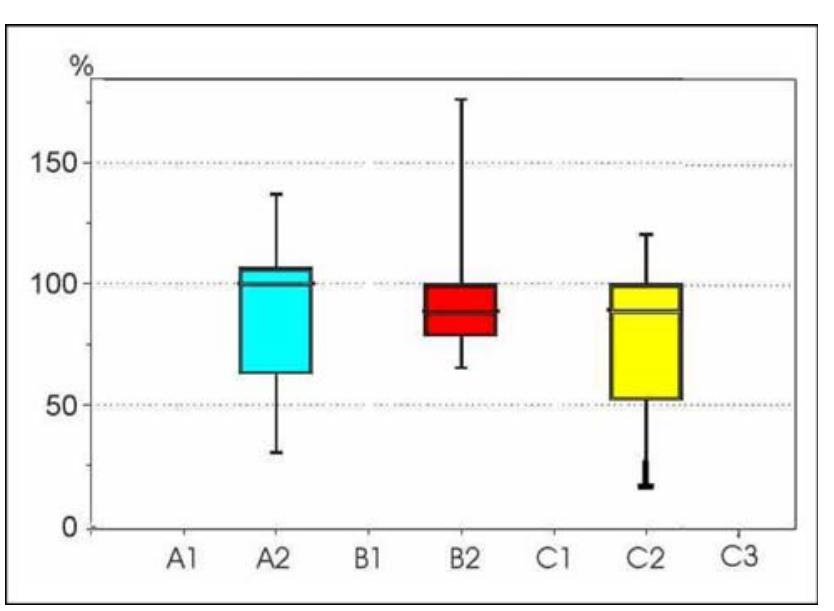

FIGURE 6 - Diagram “Box and Whiskers” of the microscopic study of injury depth average showing the percentis 5, 25, 50, 75 and 95 of each studied group. The statistic analysis through Kruskall Wallis trial did not show difference among the groups A2, B2 and C2 ( $\mathrm{p}=0.70)$

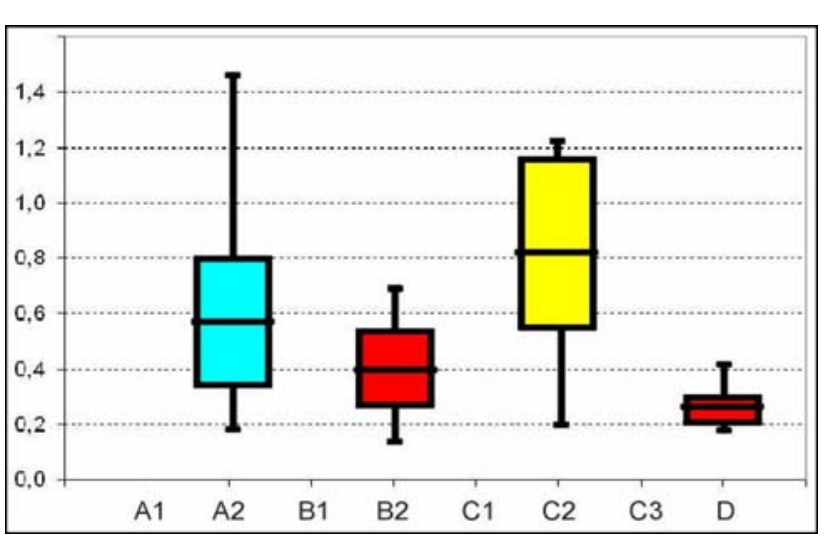

FIGURE 7 - Diagram “Box and Whiskers” of the microscopic study of the edema average quotient, showing the percentis 5, 25, 50, 75 and 90 of each studied group

The statistic analysis through Kruskall Wallis trial showed difference between the groups A2 and D; B2 and $\mathrm{C} 2$ and between $\mathrm{C} 2$ and $\mathrm{D} 2(\mathrm{p}<0,05)$

c) In the correlations through Spearman trial among all the analyzed items, when the injured mucosa percentage and the injury depth average were compared, an expressive statistic difference came out in the groups A2 and C2 $(p<0,05)$. However, a relevant statistic difference in the group B2 $(p>0,05)$ was not verified. So, in the group B2 (misoprostol + indomethacin) the lowest oedema average among the other groups A2 (omeprazole + indomethacin) and C2 (indomethacin) was verified

Correlations of the Hystopatologic Findings and the respective statistic analysis

Kruskall Wallis trial will be used in order to perform the statistic analysis of these groups, a non parametric trial, in which the average and the standard declination are not considered but it is used for the asymmetry in the distribution of the data. Besides, at the end, all the possible correlation were performed among the 5 analyzed items, using the Spearmen Correlation statistic trial for the groups A2, B2 and C2 in order to compare the results among the groups ${ }^{17}$.

\section{Discussion}

The experimental research performed with laboratory animals has been the base of the knowledge and the biological science, physiology, pharmacology evolution and the physiopatology understanding which manage the therapeutic trials. The results of these trials must be evaluated carefully and possibly will be applied in human beings. The dog, the rat and the mouse are the laboratory animals which are used in most of the trial researches, mainly in Brazil; making use of dogs is necessary larger spaces, in order they can be observed for a long period of time. Otherwise, the rat and the mouse, as they are small, they can be used in great number, taking little space, then having less costs of maintainance ${ }^{18}$.

Other important aspect to be stressed is that the interpretations of the trial results which were performed using drugs in laboratory animals depend on the period of time of the treatment and the amount and concentrations which were used. Therefore these values must be evaluated carefully several times for each animal or group of animals during the study, considering its race, weight and biological age and these controls usually are not simple and easy. Thus, comparing the results among several similar researches to get the conclusions, these factors must be considered. The conclusions of the researches which have been gotten in laboratory animals can not be interchanged totally to the human being, but indeed they provide important contributions of what possibly would occur to the human being, that the longevity of the population, in general, has risen during last decades as well as the quality of life ${ }^{9}$.

The peptic ulcers can be provided in laboratory animals by several methods, but the importance of these models for comparative studies in humans is controversy. These ulcer models, established over the past 35 years, highly resemble human ulcers in terms of both pathological features and healing process ${ }^{16,19,20}$. Despite, we preferred in this research, to named simply gastric injuries or gastric effects all the macro and microscopic lesions found in the gastric mucosa. The male and young adult Wistar rats were chosen and about the dosage of the used drugs, they were gotten from the products which are commonly found at most of the drugstores, and the same concentrations used for a $60 \mathrm{Kg}$ adult, accurately arranged for the weight of the animals, showing exactly the same effects and consequences which could occur in the humans. The NSAIDs have a primary action in the ciclooxygenases (COX-1 and COX-2) decreasing the prostaglandin synthesis. The inhibition of COX-2 seems to interfere, at least in some parts, the antipyretic, analgesic and anti-inflammatory actions of the 
NSAIDs, but the simultaneous decreasing of the COX-1 causes undesirable side effects, mainly the peptic ulcers and gastric erosions, resultant from the reduced synthesis of prostaglandins. There are many side effects referred to NSAIDs, but the individual response of the patients is still, probably, the most important ${ }^{13,14,21}$.

The celecoxib is included in a new class of NSAIDs with complication rates significantly lower than the conventionals, which also provides analgesic and antipyretic effects ${ }^{22}$. It was the first compound to be approved by “Food and Drug Administration”(FDA) to be used in the USA, in $1998{ }^{15,23}$. Regarding its pharmacologic and pharmacocinetic properties, it is believable that its action is due to the prostaglandin synthesis inhibition, mainly through the selective COX-2 inhibitor. Therefore, its therapeutical concentrations do not hinder the COX-1 which produce the prostaglandins involved in the maintenance of the gastrointestinal mucosa erosion, in the aggregation of the platelets and in the kidney action ${ }^{24,25}$.

All the "coxibs", due to the saving of COX-1, were introduced as a new nonsteroidal anti-inflammatory class having equivalent efficacy. Recently other medicaments of the same group have risen in the market, the etoricoxib, the valdecoxib. At last, the parecoxib the first specific inhibitor of the COX-2 for parental use has also been introduced for clinical use ${ }^{22,25}$.

It is important to emphasize that the therapeutical conventional uses of the indomethacin develop undesirable symptoms in $35 \%$ to $50 \%$ of the patients and about $20 \%$ of them need to stop the treatment. Most of the side effects depend on the prescribed dosage. The complaints and the gastrointestinal complications are the most relevant and consist in anorexia, nausea and abdominal pain. Simple ulcers or multiple ulcerations in all the upper gastrointestinal treatment have been described, sometimes with perforations and hemorrhage. The hidden loss of blood in the excrement can cause anemia, even without ulceration. It must not be used by pregnant woman, fosters, professionals which work on machines or patients who have psychiatric disorder, epilepsy or parkinsonism and is also formally counter indicated to people who have kidney illness or stomach or intestine ulcer injuries ${ }^{9,14,26,27}$.

Laudanno et al. ${ }^{28}$ studying the effects of ulcerogenic doses of celecoxib and indomethacin on Wistar rats gastric mucosa showed that celecoxib does not induce gastrointestinal lesions in healthy mucosa. However, celecoxib given after indomethacin aggravated antrum gastric ulcers, intestinal massive necrosis and death were observed in all the rats. They concluded that celecoxib ampliflies the gastrointestinal lesions induced by indomethacin.

Coppelli et al. ${ }^{29}$ recently studied the gastric effects of celecoxib in rats by measuring gastric potential difference and mucosal lesions. The results indicated that celecoxib did not alter gastric mucosal barrier nor induced mucosal lesions in healthy rat gastric mucosa.
The pharmacological and pharmacokinetic effects of the omeprazole, used to treat gastritis, peptic ulcers and esophagitis, result in the reduction of the gastric secretion through a high selective action, providing specific decreasing of the enzyme $\mathrm{H}^{+}, \mathrm{K}^{+}$- ATPase (proton pump) in the parietal cells, having no action in the acetylcholine and histamine receptors. Therefore, there are just small changes in the gastric juice, pepsin secretion and intrinsic factor and do not affect the gastric motility ${ }^{11,27}$.

The capacity of several prostagladin analogous to control and prevent the gastric ulceration, known as cytoprotection, is a very important therapeutical property.

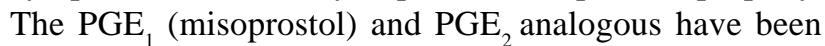
studied clinically, once they are predominantly synthesized by the gastric mucosa, decreasing the acid secretion and bicarbonate. The prostaglandins protects the gastric mucosa of animals against several ulceration attack. The ulceration properties of nonsteroidal anti-inflammatories which hinder the prostaglandin syntheses interfere in the regular gastric action, therefore several prostaglandin analogous which had a slow metabolism were developed and tested in humans ${ }^{4.11,25}$.

Misoprostol is a powerful abortive and must not be used by pregnant women or women who can be pregnant, this is a very important factor which can also limit its use ${ }^{30}$. The specific literature studies in humans emphasizes that peptic ulcers were healed in eight weeks with the inhibitor of proton pump - omeprazol (83\%), when compared to the prostaglandin analogous - misoprostol (74\%). Moreover, the side effects, such as diarrhea and abdominal pain were more commonly in patients who were treated with misoprostol. Clinical studies which aim to evaluate the cost benefit in the prevention of peptic ulcer caused by conventional NSAIDs caused by NSAIDs, showed comparisons between omeprazol and misoprostol. Omeprazol is more efficient and has better cost benefit in the treatment of gastric and duodenal ulcers. Therefore, omeprazol is the choice for ulcer treatment along with the NSAIDs, taking as basis its efficiency, tolerance and safety $-20 \mathrm{mg}$ ideal dosage once a day ${ }^{31,32}$.

Topaloglu et al. ${ }^{33}$ produced acute gastric mucosal lesions in Wistar rats using Brodie's protocol (stress method) and then administrated omeprazole or famotidine. They concluded that omeprazole prevents acute gastric mucosal erosions more effectively than famotidine. Okabe et al. ${ }^{20}$ in recent overview about acid ulcer models reported many researchs of anti-secretory drugs, mucosal defense agents, gene therapy with epidermal growth factor, vascular endothelial growth factor, nitric oxid and others involved in experimental ulcer healing. Similar experimental research which had been performed here was not found in the examined literature. The results showed expressive differences of values, regarding the amount of lesions caused by the indomethacin in the gastric mucosa of rats, when compared to the amount of lesions caused by celecoxib. The celecoxib not caused macro and microscopic gastric lesions, even when administrated in high doses (200 $\mathrm{mg} / \mathrm{rat})$. About the average of the edema, the results show 
expressive statistics difference among the groups, and the group of animals, which was given misoprostol as cytoprotection, presented a lower average compared to the group which was given omeprazole $(\mathrm{p}<0.05)$. Besides, omeprazole and misoprostol have not seemed to be completely effective in the prevention of the injuries caused by indomethacin.

Consequently, these data, once more, confirm the importance of the finding macro and microscopic comparisons. These new NSAIDs class, having less injurious effect in the gastric mucosa have a higher cost when compared to conventional drugs, but certainly they are a new therapeutical tendency regarding the efficacy of based in better quality of life and reduction of the patients' side effect rate. Meanwhile these advantages mean more than such costs, which is primordial in order celecoxib can start being prescribed as a choice drug for certain diseases instead of prescription of conventional NSAIDs which have lower costs related to preventive cytoprotection. Certainly, news experimental and clinical researchs, including NSAIDs and their pharmacological actions and their side effects in the gastroduodenal mucosa, are necessary in the future, trying to make clear controversial issues which still are.

\section{Conclusions}

The indomethacin on the applied concentration causes a great number of macroscopic and microscopic injuries to gastric mucosa of rats when compared to celecoxib which does not cause lesions. Omeprazole and misoprostol on the applied concentrations do not present macroscopic and microscopic effectiveness on the gastric cytoprotection when applying indomethacin. Considering the microscopic analysis of the average of the edema, the group of animals, which was given misoprostol as cytoprotection, presented a lower average compared to the group which was given omeprazole.

\section{References}

1. Bateman DN. NSAID'S: Time to re-evaluate gut toxicity. Lancet. 1994; 343: 1051-2.

2. Paulus HE. FDS Artthritis Advisory Committee meeting: postmarketing surveillance of nonsteroidal antiinflammatory drugs. Arthritis Rheumatol. 1985;28: 1168-9.

3. Schneider EL. Aging in the third millennium. Science.1999; 283:796-7.

4. Schmassmann A. Mechanisms of ulcer healing and effects of nonsteroidal anti-inflammatory drugs. Am J Med. 1998;104:43S-51S.

5. Griffin $\mathrm{Mr}$. Epidemiology of nonsteroidal antiinflammatory drug- associated gastrointestinal injury. Am J Med.1998;104(suppl.1):23S-29S.

6. Fries JF. NSAID gastropathy: the second most deadly rheumatic disease? Epidemiology and risk appraisal. J Rheumatol.1991; 18(suppl. 28): 6-10.

7. Vreeburg EN, Snel P, De Brujine JW. Acute upper gastrointestinal bleeding in the Amsterdam area : Incidence, diagnosis, and clinical outcome. Am J
Gastroenterol. 1997; 92:236-43.

8. Segal, WN, Cello JP. Hemorrhage in the upper gastrointestinal tract in the older patient. Am J Gastroenterol.1997; 92: 42-6.

9. Mccarthy DM . Nonsteroidal antiinflammatory drug induced ulcers : management by traditional therapies. Gastroenterology.1989; 96:662-74.

10. Barrison I . Prophylaxis against non-steroidal induced upper gastrointestinal side effects. Ann Rheumatol Dis. 1991; 50: 207-9.

11. Brunton LL. Fármacos para controle da acidez gástrica e tratamento de úlceras pépticas. In: Goodman LS, Gilman A, Hardman JG. As bases farmacológicas da terapêutica. 9.ed. Rio de Janeiro: Mc Graw Hill; 1996. p. 663-74.

12. Smith WL. Prostanoid biosynthesis and mechanism of action. Am J Physiol.1992; 268:181-91.

13. Borda IT, Koff RS. Nsaids. A profile of adverse effects. Philadelphia: Hanley and Belfus Inc; 1992.

14. Gabriel SE, Jaakkirnainen L, Bombardier C. Risk for serious gastrointestinal complications related to use of nonsteroidal antiinflammatory drugs: a meta-analysis. Ann Intern Med.1991; 115 (suppl.1): 787-96.

15. Whelton A. Renal aspects of treatment with conventional nonsteroidal anti - inflammatory drugs versus cyclooxygenase -2 specific inhibitors. Am J Med. 2001; 110:33S-42S.

16. Takagi K, Okabe S, Saziki, R. A new method for the production of chronic gastric ulcer in rats and the effect of several drugs on its healing. Jpn Pharmacol.1969; 19:418-26.

17. Conover WJ. Practical nonparametric statistics. New York: John Wiley \& Sons; 1971.

18. Bralow SP. Experimental gastric carcinogenesis. Digestion. 1972; 5: 290-310.

19. Silen W. Experimental models of gastric ulceration and injury. Am Phys Soc. 1998;24:395G-402G.

20. Okabe S, Amagase K. An overview of acetic acid ulcer models - the history and state of the art of peptic ulcer research. Biol Pharmacol Bull. 2005; (8):1321-41.

21. Brooks P. Use and benefits of nonsteroidal antiinflammatory drugs. Am J Med.1998; 104(suppl.1): 43S-51S.

22. Cheer SM, Goa Kl. Parecoxib (parecoxib sodium). Drugs. 2001; 61: 1133-41.

23. Chan CC, Boyce S, Brideau C. Rofecoxib (VioX.MK0966,4- (4 methylsulfonylphenyl)-3-phenyl-2-(5H)furanone): a potent and orally active cyclooxygenase-2 inhibitor-pharmacological and biochemical profiles. J Pharmacol Exp Ther. 1999; 290(suppl.1): 551-60.

24. Silverstein FE, Faich G, Goldstein JL . Gastrointestinal toxicity with celecoxib vs nonsteroidal anti-inflammatory drugs for osteoarthritis and rheumathoid arthritis. J Am Med Assoc. 2000;284:1247-55.

25. Cannon GW, Breedveld Fc. Efficacy of cyclooxygenase-2 specific inhibitors. Am J Med. 2001;110(suppl.1): 6S-12S.

26. Jonsson B, Wahlqvist P. Management of nonsteroidal anti-inflammatory drug-associated lesions: a costeffectiveness perspective. Am J Med.1998;104(suppl.1): 81S-8S.

27. Mctavish D, Buckley MM, Heel RC. Omeprazole: an updated review of its pharmacology and therapeutic use 
in acid-related disorders. Drugs.1991; 42:138-70.

28. Laudanno OM, Esnarriaga J M, Cesolari JA, Maglione CB, Aramberry LJ, Sambrano JS, Piombo G, Rista L. Celecoxib vs indomethacin and acute gastric lesions in rats. Medicina. 2000;60(2):221-4.

29. Coppelli G, Guaita E, Spaggiari S, Coruzzi G. Gastric effects of the selective cyclooxygenase- 2 inhibitor, celecoxib, in the rat. Dig Liver Dis. 2004;36(4):265-70.

30. Collins PW. Misoprostol: discovery, development, and clinical applications. Med Res Rev.1990; 10:149-72.
31. Hawkey CJ . Progress in prophylaxis against nonsteroidal anti- inflammatory drug-associated ulcers and erosions. Am J Med.1998; 3A(104): 67S-74S.

32. Yeomans Nd. New data on healing of nonsteroidal antiinflammatory drug-associated ulcers and erosions. Am J Med.1998; 104:56S-61S.

33. Topaloglu U, Muftuoglu T, Akturk Z, Ekinci H, Peker $\mathrm{O}$, Unalmiser S. Omeprazole is more effective than famotidine for preventing acute gastritis in rats. Surg Today. 2004;34(8):690-4.

\section{Correspondence:}

Miriam Elias Cavallini

Rua Tiradentes, 490/62

13400-760 Piracicaba - SP Brazil

Phones: (55 19)3433-2040 / 9788-4343

mielias@merconet.com.br
Conflict of interest: none Financial source: none

Received: December 18, 2005

Review: January 22, 2006

Accepted: February 13, 2006

How to cite this article:

Cavallini ME, Andreollo NA, Metze K, Araújo MR. Omeprazole and misoprostol for preventing gastric mucosa effects caused by indomethacin and celecoxib in rats. Acta Cir Bras. [serial on the Internet] 2006 May-June 21(3). Available from URL: http://www.scielo.br/acb.

*Color figures available from www.scielo.br/acb

\title{
REGIONAL DO CEARÁ DA SOBRADPEC
}

\author{
Presidente Luiz Gonzaga Porto Pinheiro
}

\section{Instalou o LABORATÓRIO DE CIRURGIA EXPERIMENTAL PROF. DR. SAUL GOLDENBERG}

\author{
Cirurgia Radioguiada \\ -Linfonodo Sentinela-
}

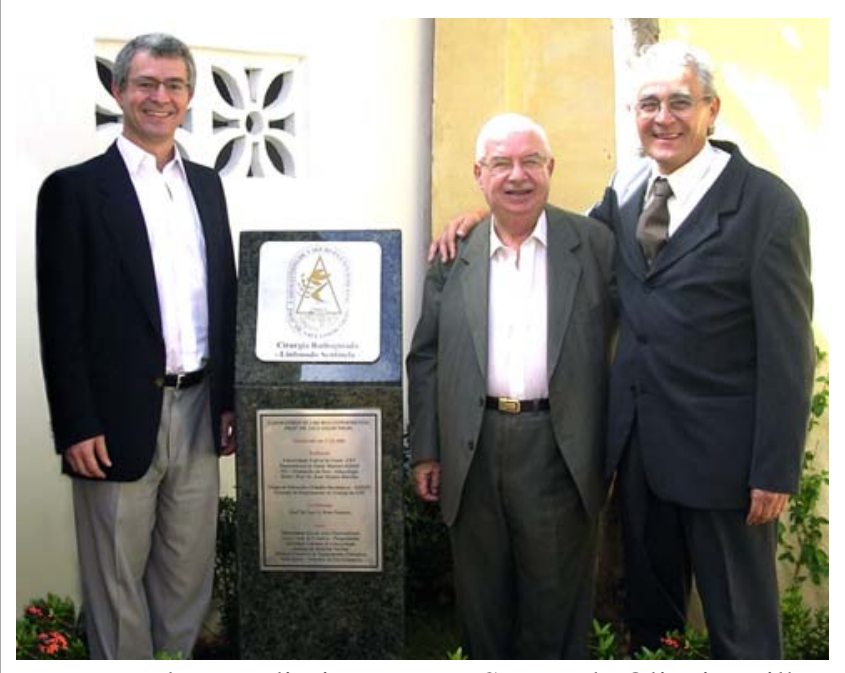

Da esquerda para direita: Renato Santos de Oliveira Filho, Saul Goldenberg, Luiz Gonzaga Porto Pinheiro
Iniciativa do Grupo de Educação e Estudos Oncológicos (GEEON) e da Faculdade de Medicina da Universidade Federal do Ceará

A solenidade de inauguração do Laboratório, com posicionamento de placa comemorativa, foi realizada em 17 de março de 2006, em Fortaleza-Ceará. 